\title{
GEOLOGIC CONSTRAINTS ON THE UPPER LIMITS OF RESERVE GROWTH
}

By Richard G. Stanley ${ }^{1}$

Open-File Report 01-265

2001

This report is preliminary and has not been reviewed for conformity with U.S. Geological Survey editorial standards or with the North American Stratigraphic Code. Any use of trade, firm, or product names is for descriptive purposes only and does not imply endorsement by the U.S. Government.

\section{U. S. DEPARTMENT OF THE INTERIOR}

U. S. GEOLOGICAL SURVEY

${ }^{1}$ U. S. Geological Survey, 345 Middlefield Road MS 969, Menlo Park, CA 94025 


\title{
Geologic Constraints on the Upper Limits of Reserve Growth
}

\author{
By \\ Richard G. Stanley \\ INTRODUCTION
}

Early in 1999, the Geologic Division of the U.S. Geological Survey distributed its first "Geologic Division Unified Prospectus," a 31-page document that summarized the Division's ongoing research projects and solicited preproposals for new projects. In the section on Energy Resource Studies, the Prospectus requested preproposals that addressed the phenomenon of reserve growth in oil and gas accumulations. In response to this request, I spent several weeks investigating the subject of research growth, mainly through literature review and personal communications with other interested scientists. On April 5, 1999, I submitted to the Geologic Division a preproposal entitled "Geologic Constraints on the Upper Limits of Reserve Growth." This preproposal (1) put forth the idea that geologically-based estimates of in-place oil and gas could be used to forecast the upper limits of reserve growth and ultimate recovery, and (2) proffered a research strategy to test the feasibility of this new idea, using several old and large California oil and gas fields as examples.

This preproposal was accepted by the Division on May 5, 1999. However, I decided not to submit a formal proposal after learning that the National Oil and Gas Assessment Project (NOGA) was already committed to using a petroleumengineering approach (rather than a geological approach) in which estimates of reserve growth and ultimate recovery are calculated for large groups of oil and gas fields using statistical extrapolations from historical records of production and estimated reserves.

Now, about two years later, it appears that the ideas in my original preproposal are gaining wider acceptance, and that at least some of these ideas might be used in a NOGA assessment of the San Joaquin basin, California, to be completed during 2003. Therefore, it seems timely and appropriate to publish the preproposal in which the ideas first appeared. Most of this Open-File Report consists of the text of the preproposal almost exactly as it was submitted to the Geologic Division during 1999, with minor changes in formatting. The report concludes with a brief "Bibliography" containing scientific publications that significantly influenced the writing of the preproposal. Citations of the published literature were not included in the original preproposal owing to space limitations established by the Geologic Division.

\section{OVERVIEW}

For many oil and gas fields, estimates of ultimate recovery (the sum of cumulative production plus estimated reserves) tend to increase from one year to the next, and the gain is called reserve growth. Forecasts of reserve growth by the U.S. Geological Survey rely on statistical analyses of historical records of oil and gas production and estimated reserves. The preproposal in this Open-File Report suggests that this traditional petroleum-engineering approach to reserve growth might be supplemented, or at least better understood, by using geological data from individual oil and gas fields, 3-D modeling software, and standard volumetric techniques to estimate in-place volumes of oil and gas. Such estimates, in turn, can be used to constrain the upper limits of reserve growth and ultimate recovery from those fields. 


\title{
ACKNOWLEDGMENTS
}

I thank Ken Bird, Harry Cook, Ted Dyman, Neil Fishman, Don Gautier, Scott Hector, Caroline Isaacs, Paul Lillis, Les Magoon, Rex Sanders, Chris Schenk, and Mahendra Verma for informative discussions, and Harry Cook for a very helpful technical review.

\section{TEXT OF THE PREPROPOSAL OF APRIL 5, 1999}

\author{
USGS Geologic Division \\ Preproposal-FY 2000
}

IDENTIFYING INFORMATION

Project title: Geologic constraints on the upper limits of reserve growth

Geographic area: United States of America

Project start date: October 1, 1999

Project end date: September 30, 2001

Project chief: Richard G. Stanley

Region/Division/Team/Section: Western/Geologic/National Cooperative Geologic Mapping/Energy

Email: rstanley@usgs.gov

Phone: 650-329-4918

Fax: 659-329-4975

Mail address: 345 Middlefield Road, MS 969, Menlo Park, CA 94025

Program(s): Energy Resources

Geologic Division goal/element/activity/sub-activity:

Goal 3: Advance the understanding of the nation's energy and mineral resources in a global geologic, economic, and environmental context.

Element 3.1: Domestic Resource Studies.

Activity 3.1.1: Energy Resource Studies.

Sub-activity 3.1.1.2: National Oil and Gas Assessment (NOGA).

NARRATIVES

Project summary: For many oil and gas fields, estimates of ultimate recovery (the sum of cumulative production plus reserves) are made each year, and the estimates usually increase from one year to the next; this phenomenon is called "reserve growth." Previous USGS forecasts of reserve growth have relied on statistical "growth functions" derived from disparate data sets, but the results show wide variations and are controversial. Nevertheless, reliable forecasts are essential because reserve growth is thought to constitute more than half of the 110 billion barrels of recoverable oil resources remaining in the United States. This project will investigate the feasibility of using geologically-based estimations of in-place oil and gas to establish the upper limits of reserve growth.

Project objectives and strategy: "Reserve growth" (also known as "field growth" and "inferred reserves") refers to the changes in estimated ultimate recovery (the sum of past production plus remaining reserves) that typically occur as oil and gas fields are 
developed and produced. When a new field is discovered, initial estimates of reserves are made to determine the field's commercial potential. As more wells are drilled and the field is developed, estimates of reserves are revised (usually upward) as a result of changing circumstances that may include discoveries of new and deeper pools, lateral extensions of older pools, infill drilling, enhanced production from water floods or gas injection, application of new technology, changes in oil prices and production costs, and other factors.

The 1995 National Assessment of United States Oil and Gas Resources (including Alaska) concluded that there are about 110 billion barrels of technically recoverable oil onshore and in state waters (including Alaska). This estimate includes (a) about 20 billion barrels of discovered and measured reserves; (b) about 30 billion barrels of undiscovered resources; and (c) about 60 billion barrels attributable to reserve growth in known fields. These figures imply that reserve growth is the biggest single source of additions to proven reserves in the United States.

Previous USGS forecasts of reserve growth have varied greatly, as shown in the chart below (using figures for the lower 48 states only):

\begin{tabular}{l|cccc}
\hline Publication year & 1975 & 1981 & 1989 & 1995 \\
Oil, BBO (billion barrels) & 14 & 23 & 15 & 47 \\
Gas, TCF (trillion cubic feet) & 139 & 132 & 90 & 290 \\
\hline
\end{tabular}

None of these forecasts were based on geological data; instead, all of them were made on the basis of statistical extrapolations involving the use of "growth functions" that were mathematically derived from historical records of production and estimated reserves. The differences between forecasts are thought to arise mainly from (a) differences in assumptions and mathematical procedures, and (b) the use of disparate data sets that were obtained from diverse sources and cover varying periods of time.

The principal objective of this project is to find one or more methods by which easily-obtainable geological data can be used to infer the upper limits of reserve growth for individual fields and for aggregates of fields in large areas (including plays, petroleum systems, basins, and provinces). Our proposed approach is as follows:

(1) Identify mature, geologically simple oil fields for which there are reliable data on production and reserves for periods of 50 years or more, and for which there is reliable geological information on parameters such as trap style, reservoir type and quality, hydrocarbon type and quality, oil saturation, etc.

(2) Using all available geological data, 3-D modeling software, and standard volumetric techniques, prepare 3-D geometric models of the oil and gas accumulations and calculate the amounts of in-place oil and (or) gas.

(3) Estimate the amounts of recoverable oil and (or) gas using recovery factors that (a) take into account the potential impacts of oil quality, reservoir type, and other geologic factors, and (b) assume the same economic and technological conditions as the statistically-based calculations of field growth and ultimate recovery.

(4) Compare and contrast the geologically-based estimates of in-place and recoverable oil and gas with previous, statistically-based estimates of ultimate recovery; analyze the differences and similarities in the estimates made by these different approaches for fields of varying ages, trap styles, reservoir types, and hydrocarbon types; and draw conclusions regarding the value and practicality of using estimates of in-place oil and gas to infer the upper limits of reserve growth for individual fields. 
(5) Formulate and test additional hypotheses that are suggested by examination of the data.

Initially, this project will focus on selected fields in the San Joaquin and Sacramento basins of California because (a) fields in these areas are large, geologically diverse, and show varying amounts of reserve growth, and therefore will provide abundant opportunities to formulate and test hypotheses regarding the geologic controls on reserve growth; (b) abundant information on the geology, production history, and historical estimates of reserves of individual fields in these areas is already in-house or readily available; (c) we can work efficiently in these areas because we have much recent personal experience there; (d) we have numerous personal contacts in local governmental agencies and the oil industry who are active in these areas and can provide important information that might otherwise be inaccessible; and (e) there are many old and large fields in these areas that continue to be major producers of petroleum; some examples are shown in the following chart.

\begin{tabular}{|c|c|c|c|}
\hline Field & Discovery year & Cumulative production to $12 / 31 / 97$ & 1997 production \\
\hline Midway-Sunset (oil) & 1894 & $2.4 \mathrm{BBO}$ & 61 million barrels \\
\hline Kern River (oil) & 1899 & $1.6 \mathrm{BBO}$ & 49 million barrels \\
\hline South Belridge (oil) & 1911 & $1.1 \mathrm{BBO}$ & 43 million barrels \\
\hline Elk Hills (oil) & 1911 & $1.1 \mathrm{BBO}$ & 22 million barrels \\
\hline Rio Vista (gas) & 1936 & $3.4 \mathrm{TCF}$ & 12 billion cubic feet \\
\hline
\end{tabular}

Potential impacts and major products: Because this is an exploratory project, the outcomes are difficult to predict. We anticipate that this project will provide one or more new approaches to estimating the upper limits of reserve growth; that this new methodology will be applied in the National Oil and Gas Assessment (NOGA) of the San Joaquin and other California basins to begin in FY 2001; and that the same or similar approaches will be useful in petroleum resource assessments elsewhere in the United States and the world. In addition, the project will produce new, digital 3-D geological models and new, geologically-based estimates of in-place oil and gas for many fields in California and perhaps other parts of the United States; these models, in addition to their utility in studies of reserve growth, will also provide analogs for estimating the sizes, numbers, and geologic characteristics of undiscovered fields. Other possible outcomes may include additional testable hypotheses; our analysis may show, for example, that statistical methods are reliable predictors of reserve growth in certain types of fields (e.g., those with sandstone reservoirs and light oil), whereas oil-in-place calculations are preferred for others (e.g., those with fractured shales or diatomites and heavy oil). Project results will be presented at technical and professional meetings and submitted for publication in technical journals and (or) USGS publications.

Collaborators, clients: We anticipate that the principal client of this project will be the USGS National Oil and Gas Assessment. We expect that the principal collaborators will be (1) Caroline Isaacs (USGS, retired), who has offered to provide information and expertise obtained during her intensive studies of reserve growth during the 1995 National Assessment; and (2) the California Division of Oil, Gas, and Geothermal Resources, a major source of information on the geology, production, and reserves of oil and gas fields. Additional collaborators and clients will be sought from other government agencies and the oil industry. We are willing to join with others in a single large project on reserve growth. 
PROJECT SUPPORT REQUIREMENTS

Names and expertise of key project staff:

FY 2000 to FY 2002:

Lillis, Paul G. (Petroleum geology, organic geochemistry): 2-6 pay periods

Magoon, Leslie B. (Petroleum geology, organic geochemistry): 2-6 pay periods

Stanley, Richard G. (Petroleum geology, California regional geology: 13 pay periods

Required expertise for which no individual has been identified:

FY 2000 to FY 2002: Petroleum engineer; GIS and other technical support.

Major equipment/facility needs:

FY 2000 to FY 2002: 3-D modeling, GIS, and statistical software; possibly some computer hardware; USGS petroleum geochemistry laboratory and supplies in Denver.

Approval:__Date:

Approval:_ Date:

Approval:_ Date:

\section{BIBLIOGRAPHY}

Arrington, J.R., 1960, Predicting the size of crude reserves is key to evaluating exploration programs, and here's a practical way to calculate reserves: Oil and Gas Journal, v. 58, no. 9 (February 29, 1960), p. 130-134.

Attanasi, E.D., Mast, R.F., and Root, D.H., 1999, Oil, gas field growth projections-wishful thinking or reality?: Oil and Gas Journal, v. 97, no. 14 (April 5) p. 79-81.

Attanasi, E.D., and Root, D.H., 1994, The enigma of oil and gas field growth: American Association of Petroleum Geologists Bulletin, v. 78, no. 3, p. 321-332.

California Division of Oil and Gas, 1982, California oil and gas fields, volume 3, northern California (4th ed.): Sacramento, Calif., California Department of Conservation, Publication TR10, unpaginated. 1985, California oil and gas fields, volume 1, central California (3d ed.): Sacramento, Calif., California Department of Conservation, Publication TR11, unpaginated.

California Division of Oil, Gas, and Geothermal Resources, 1998, 1997 Annual Report of the State Oil and Gas Supervisor: Sacramento, Calif., California Department of Conservation, Publication PR06, $267 \mathrm{p}$.

Dodge, J.F., Pyle, H.C., and Trostel, E.G., 1941, Estimation by volumetric methods of recoverable oil and gas from sands: American Association of Petroleum Geologists Bulletin, v. 25, no. 7, p. 1302-1326.

Garb, F.A., and Smith, G.L., 1987, Estimation of oil and gas reserves [chapter 12] in Bradley, H.B., ed., Petroleum engineering handbook (3d printing): Richardson, Tex., Society of Petroleum Engineers, p. 40-1-40-38.

Gautier, D.L., Dolton, G.L., Takahashi, K.I., and Varnes, K.L., eds., 1995, U.S. Geological Survey 1995 national assessment of United States oil and gas resources-results, methodology, and supporting data: U.S. Geological Survey Digital Data Series DDS-30. 
Kim, E.M., and Fisher, W.L., 1999, Play disaggregation reveals key Texas gas growth trends: Oil and Gas Journal, v. 97, no. 8 (Feb. 22), p. 70-73.

1999, Further growth lies ahead for South Texas Wilcox plays: Oil and Gas Journal, v. 97, no. 9 (Mar. 1), p. 79-83.

Marsh, G.R., 1971, How much oil are we really finding?: Oil and gas Journal, v. 69, no. 14 (April 5), p. 100-104.

Mast, R.F., and Dingler, Janet, 1975, Estimates of inferred + indicated reserves for the United States by States, in Miller, B.M., Thomsen, H.L., Dolton, G.L., Coury, A.B., Hendricks, T.A., Lennartz, F.E., Powers, R.B., Sable, E.G., and Varnes, K.L., Geological estimates of undiscovered recoverable oil and gas resources in the United States: U.S. Geological Survey Circular 725, p. 73-78.

Mast, R.F., Dolton, G.L., Crovelli, R.A., Root, D.H., Attanasi, E.D., Martin, P.E., Cooke, L.W., Carpenter, G.B., Pecora, W.C., and Rose, M.B., 1989, Estimates of undiscovered conventional oil and gas resources in the United States-a part of the nation's energy endowment: U.S. Geological Survey and Minerals Management Service, $44 \mathrm{p}$.

Megill, R.E.,1993, New data unearths wider view: American Association of Petroleum Geologists Explorer, v. 14, no. 5 (May), p. 22-23. 1993, Those old discoveries keep growing: American Association of Petroleum Geologists Explorer, v. 14, no. 6 (June), p. 30-31.

Root, D.H., 1981, Estimation of inferred plus indicated reserves for the United States, in Dolton, G.L., Carlson, K.H., Charpentier, R.R., Coury, A.B., Crovelli, R.A., Frezon, S.E., Khan, A.S., Lister, J.H., McMullin, R.H., Pike, R.S., Powers, R.B., Scott, E.W., and Varnes, K.L., Estimates of undiscovered recoverable conventional resources of oil and gas in the United States: U.S. Geological Survey Circular 860, p. 83-87.

Root, D.H., and Mast, R.F., 1993, Future growth of known oil and gas fields: American Association of Petroleum Geologists Bulletin, v. 77, no. 3, p. 479-484.

U.S. Geological Survey, 1996, The importance of reserve growth to the nation's supply of natural gas: U.S. Geological Survey Fact Sheet FS-202-96, online at http:// greenwood.cr.usgs.gov/energy/factshts/202-96/FS-202-96.html. 1997, The uncertainty of estimating growth of hydrocarbon reserves: U.S. Geological Survey Fact Sheet (not numbered), online at http://energy.usgs.gov/ factsheets/HydroGrowth/ estimating.html.

U.S. Geological Survey National Oil and Gas Resource Assessment Team, 1995, 1995 National Assessment of United States Oil and Gas Resources: U.S. Geological Survey Circular 1118, $20 \mathrm{p}$.

Willis, Robin, 1953, How to determine the recoverable reserves of an oil property, part 1: Petroleum World and Oil, November 26, 1953, p. 14-19.

1953, How to determine the recoverable reserves of an oil property, part 2: Petroleum World and Oil, December 31, 1953, p. 14-18. 